Original Research Paper

\title{
Edukasi Sadar Bencana Melalui Sosialisasi SOP Mitigasi Bencana Banjir dan Gempa Bumi di SMKN 1 Sekotong Kecamatan Sekotong Kabupaten Lombok Barat
}

\author{
*Nigia Deta Anggriani, Riri Sahri Soumi, Septiani Purnama Sari, Athirah Syaima Nursyamsa, Ichsan \\ Fauzi Pangestu, Sabila, Dian Aprilita, Dini Eka Fitriani, Ni Nyoman Nopiantari Sasmita, Muhammad \\ Andrian Wijaya
}

${ }^{1}$ FKIP, Universitas Mataram, Mataram, Indonesia

https://doi.org/10.29303/jpmpi.v3i2.1410

Sitasi: Anggriani, N. D., Soumi, R. S., Sari, S. P., Nursyamsa, A. S., Pangestu, I. F. P., Sabila., Aprilita, D., Fitriani, D. E., Sasmita, N. N. N \& Wijaya, M. A. (2022). Edukasi Sadar Bencana Melalui Sosialisasi SOP Mitigasi Bencana Banjir dan Gempa Bumi di SMKN 1 Sekotong Kecamatan Sekotong Kabupaten Lombok Barat. Jurnal Pengabdian Magister Pendidikan IPA, 5(1)

Article history

Received: 11 Januari 2022

Revised: 01 Februari 2022

Accepted: 07 Februari 2022

*Corresponding Author: Nigia

Deta Anggriani, Fakultas

Keguruan dan Ilmu

Pendidikan, Universitas

Mataram, Mataram, Indonesia;

Email: zubairfkip8@ gmail.com

\begin{abstract}
Kecamatan Sekotong termasuk dalam salah satu wilayah pesisir di Kabupaten Lombok Barat. Wilayah pesisir rentan akan terjadinya bencana banjir terutama ketika memasuki musim penghujan karena adanya 2 pertemuan air yang berasal dari bukit dan air pantai pasang yang diapit oleh sungai diantara keduanya. Hal tersebut dapat berdampak lebih besar jika dibarengi oleh musim penghujan dengan intensitas yang besar dan cukup lama. Selain ancaman banjir, Kecamatan Sekotong juga memiliki potensi ancaman gempa bumi karena letaknya yang dekat dengan pesisir. Maka dari itu, tim mahasiswa KKN melakukan kegiatan sosialisasi edukasi sadar bencana SOP mitigasi bencana banjir dan gempa bumi di beberapa sekolah salah satunya di SMKN 1 Sekotong. Hampir siswa di SMKN 1 Sekotong belum pernah mendapatkan penyuluhan atau sosialisasi terkait SOP mitigasi bencana. Kegiatan sosialisasi ini bertujuan untuk memberikan pengetahuan dan kesadaran akan pentingnya mengetahui risiko, dampak serta langkahlangkah yang harus dilakukan sebelum, saat dan setelah bencana melanda.
\end{abstract}

Keywords: Sekotong, sosialisasi, pengetahuan, banjir, gempa bumi

\section{Pendahuluan}

UU No. 24 Tahun 2007 mendefinisikan bencana sebagai "peristiwa atau rangkaian peristiwa yang mengancam dan mengganggu kehidupan dan penghidupan masyarakat yang disebabkan, baik oleh faktor alam dan/atau faktor non alam maupun faktor manusia sehingga mengakibatkan timbulnya korban jiwa manusia, kerusakan lingkungan, kerugian harta benda, dan dampak psikologis". Bencana adalah terjadinya kerusakan pada pola-pola kehidupan normal, bersifat merugikan kehidupan manusia, struktur sosial serta munculnya kebutuhan masyarakat (Haryanto, 2001 : 35). Dari beberapa pengertian bencana diatas, bahwa pada dasarnya pengertian bencana secara umum yaitu suatu kejadian atau peristiwa yang menyebabkan kerusakan berupa sarana prasana maupun struktur sosial yang sifatnya mengganggu kelangsungan hidup masyarakat.

Secara umum faktor penyebab terjadinya bencana adalah karena adanya interaksi antara ancaman (hazard) dan kerentanan (vulnerability). Ancaman bencana menurut Undang-Undang Nomor 24 Tahun 2007 adalah "Suatu kejadian atau peristiwa yang bisa menimbulkan bencana". Kerentanan terhadap dampak atau risiko bencana adalah "Kondisi atau karakteristik biologis, geografis, sosial, ekonomi, politik, budaya dan teknologi suatu masyarakat di suatu wilayah untuk jangka waktu tertentu yang mengurangi kemampuan masyarakat untuk mencegah, meredam, mencapai kesiapan, dan menanggapi dampak bahaya tertentu" 
(MPBI, 2004 : 5).

Kesiapsiagaan bencana yaitu upaya-upaya yang memungkinkan masyarakat (individu, kelompok, organisasi) dapat mengatasi bahaya peristiwa alam, melalui pembentukan struktur dan mekanisme tanggap darurat yang sistematis. Tujuannya untuk meminimalkan korban jiwa dan kerusakan sarana-sarana pelayanan umum. Kesiapsiagaan bencana meliputi: upaya mengurangi tingkat risiko, formulasi Rencana Darurat Bencana (Disasters Plan), pengelolaan sumber-sumber daya masyarakat, pelatihan warga di lokasi rawan bencana (Purnama, 2017 : 8). Mitigasi didefinisikan sebagai: "Upaya yang ditujukan untuk mengurangi dampak dari bencana baik bencana alam, bencana ulah manusia maupun gabungan dari keduanya dalam suatu negara atau masyarakat."

Banjir merupakan bencana alam yang paling sering terjadi di Indonesia. Bencana banjir termasuk kejadian yang sering terjadi pada setiap datangnya musim penghujan. Banjir disebabkan oleh beberapa faktor, yaitu faktor hujan, faktor hancurnya retensi Daerah Aliran Sungai (DAS), faktor kesalahan perencanaan pembangunan alur sungai, faktor pendangkalan sungai dan faktor kesalahan tata wilayah dan pembangunan sarana dan prasarana (Maryono, 2005). Kedatangan banjir dapat diprediksi dengan memperhatikan curah hujan dan aliran air. Banjir biasanya terjadi dikarenakan meluapnya aliran sungai, danau atau lautan sebagai akibat dari hujan yang berlebihan. Kurangnya edukasi masyarakat tentang evakuasi bencana yang dapat memungkinkan kehilangan nyawa, penderitaan orang-orang dan kerusakan harta benda yang parah. Sebab, banjir bisa membawa berbagai material ringan hingga berat dan dapat merusak tanaman serta bangunan penting lainnya.

Menurut Prager (2006) dalam Pristanto (2010) mengemukakan gempa bumi merupakan getaran seismik yang disebabkan oleh pecahnya atau bergesernya bebatuan di suatu tempat dalam kerak bumi. Getaran tersebut merambat melalui tanah dalam bentuk gelombang getaran sehinga manusia yang berada di permukaan bumi merasa getaran yang akhirnya disebut gempa bumi. Jenis bencana ini bersifat merusak, dapat terjadi setiap saat dan berlangsung dalam waktu singkat. Gempa bumi dapat menghancurkan bangunan, jalan, jembatan, dan sebagainya dalam sekejap. Oleh Karena itu, masyarakat terutama remaja perlu mengetahui tentang SOP mitigasi bencana banjir dan gempa bumi.

Dusun Madak Belek dan Madak Belek II,
Desa Cendi Manik termasuk dalam salah satu desa pesisir yang didominasi oleh Bakau (Mangrove) yang menjadi potensi wisata edukasi. Potensi tersebut kemudian dikembangkan menjadi Wisata Edukasi Bagek Kembar. Selain adanya tempat edukasi wisata, juga terdapat Pembibitan Mangrove yang dinamakan dengan Nursery.

Selain potensi, berdasarkan wawancara yang dilakukan kepada perangkat desa dan masyarakat setempat bahwasanya Dusun Madak Belek dan Madak Belek II juga rentan dan berpotensi terdampak banjir. Hal tersebut terjadi karena letak dusun yang berada di antara bukit, sungai dan pesisir yang di mana ketika musim penghujan datang maka Dusun Madak Belek dan Madak Belek II menjadi tempat muara air hujan yang berasal dari bukit dan aliran sungai sehingga ketika terjadi hujan deras dalam jangka waktu yang lama bersamaan dengan laut pasang maka air akan naik dan menggenangi rumah masyarakat khususnya rumah yang dekat dengan pesisir.

Selain ancaman banjir, Pulau Lombok memiliki potensi bencana gempa bumi yang cukup tinggi, salah satunya di Kecamatan Sekotong yang sebagian besar meliputi wilayah pesisir.

Maka dari itu, pentingnya pengetahuan tentang SOP bencana banjir dan gempa bumi masih sangat rendah terutama dikalangan remaja. Edukasi SOP bencana banjir dan gempa bumi belum pernah dilakukan di SMKN 1 Sekotong, sehingga mahasiswa KKN Terpadu Universitas Mataram Tahun 2021 mengadakan sosialisasi tentang SOP mitigasi bencana banjir dan gempa bumi yang meliputi prabencana, saat bencana dan pascabencana.

\section{Metode Pelaksanaan}

Kegiatan ini difokuskan untuk memberi informasi tentang SOP mitigasi bencana banjir dan gempa bumi yang mencakup prosedur pencegahan (prabencana), saat bencana terjadi dan pascabencana.

Metode yang dilakukan dalam pengabdian ini yaitu sosialisasi, tahapannya dimulai dari observasi lapangan dan berdiskusi langsung dengan Kepala Sekolah SMKN 1 Sekotong dan Wakil Kepala Sekolah Kesiswaan. Sosialisasi dilaksanakan oleh mahasiswa KKN Universitas Mataram pada Jumat, 10 Desember 2021 yang ditujukan pada siswa kelas X, XI dan XII dan didampingi guru serta Kepala Sekolah SMKN 1 Sekotong. Kegiatan sosialisasi berlangsung di aula 
sekolah tepat ketika imtaq sekolah selesai. Kegiatan ini bertujuan untuk memberikan informasi kepada siswa SMKN 1 Sekotong tentang SOP mitigasi bencana banjir dan gempa bumi. Sosialisasi ini dapat meningkatkan kesiapsiagaan masyarakat dalam mengurangi dampak dan risiko bencana.

Dengan demikian pengetahuan siswa SMKN 1 Sekotong tentang SOP mitigasi bencana sangat diperlukan untuk pengetahuan agar mengetahui cara pencegahan, dampak serta risiko bencana yang bisa terjadi kapan saja.

Berdasarkan siklus waktunya, kegiatan penanganan bencana dapat dibagi 3 kategori:

a. Kegiatan sebelum bencana terjadi (mitigasi).

b. Kegiatan saat bencana terjadi (perlindungan dan evakuasi).

c. Kegiatan pascabencana.

SMKN 1 Sekotong dipilih sebagai sasaran atau peserta dari kegiatan sosialisasi ini karena letak sekolah yang masih berada di kawasan Desa Cendi Manik dan hampir sebagian besar siswa SMKN 1 Sekotong tidak mengetahui SOP mitigasi bencana banjir dan gempa bumi serta belum pernah mengikuti kegiatan penyuluhan atau sosialisasi SOP mitigasi bencana sebelumnya. Kegiatan penyuluhan pada siswa ini dilaksanakan untuk meningkatkan pemahaman dan kesadaran siswa SMKN 1 Sekotong akan pentingnya mengetahui tahap-tahap yang dilakukan prabencana, saat bencana dan pascabencana.

\section{Hasil dan Pembahasan}

Desa Cendi Manik merupakan desa di daerah pesisir, dengan potensi curah hujan cukup tinggi yang dapat menyebabkan bencana banjir, serta frekuensi gempa bumi yang cukup tinggi di Pulau Lombok yang dapat berpengaruh langsung pada kerusakan sarana hingga ekonomi di daerah yang terdampak. Sosialisasi dengan tujuan untuk pencegahan atau penanggulangan bencana banjir dan gempa bumi wajib untuk diberikan kepada seluruh lapisan masyarakat tidak terkecuali kepada siswa di SMKN 1 Sekotong.

Kegiatan sosialisasi yang dilakukan di SMKN 1 Sekotong dengan dibantu oleh kepala sekolah, 4 orang guru, 3 mahasiswa KKN Universitas Mataram sebagai pemateri, serta 47 siswa yang hadir sebagai peserta. Kegiatan sosialisasi yang dilakukan berupa edukasi sadar bencana tentang SOP mitigasi bencana banjir dan gempa bumi. Sosialisasi edukasi ini dapat menjadi salah satu langkah atau solusi yang diberikan untuk meningkatkan pengetahuan akan pentingnya kesadaran mengetahui langkah-langkah yang harus dilakukan sebelum, saat, dan setelah bencana banjir ataupun gempa bumi melanda.

Materi yang dibahas dalam sosialisasi tersebut adalah:

1. Mitigasi banjir

a. Sebelum banjir

* Penataan daerah aliran sungai

* Pembangunan sistem pemantauan dan peringatan banjir

* Tidak membangun bangunan di bantaran sungai

* Buang sampah di tempat sampah

* Pengerukan sungai

* Penghijauan hulu sungai

b. Saat banjir

\$ Matikan listrik

* Mengungsi ke daerah aman

* Jangan berjalan dekat saluran air

* Hubungi instansi yang berhubungan dengan penanggulangan bencana

c. Setelah banjir

* Bersihkan rumah

* Siapkan air bersih untuk menghindari diare

* Waspada terhadap binatang berbisa atau penyebar penyakit yang mungkin $\underline{\text { ada }}$

* Selalu waspada terhadap banjir $\underline{\text { susulan }}$

2. Mitigasi gempa bumi

a. Sebelum gempa

* Mendirikan bangunan sesuai aturan baku (tahan gempa)

* Kenali lokasi bangunan tempat Anda tinggal

* Tempatkan perabotan pada tempat yang proporsional

* Siapkan peralatan seperti senter, P3K. makanan instan, dll

* Periksa penggunaan listrik dan gas

* Catat nomor telepon penting

* Kenali jalur evakuasi

\# Ikuti kegiatan simulasi mitigasi bencana gempa

b. Ketika Gempa

* Tetap tenang

* Hindari sesuatu yang kemungkinan akan roboh, kalau bisa ke tanah lapang

* Perhatikan tempat Anda berdiri, kemungkinan ada retakan tanah 
Turun dari kendaraan dan jauhi pantai

c. Setelah gempa

Cepat keluar dari bangunan. Gunakan tangga biasa

4 Periksa sekitar Anda. Jika ada yang terluka, lakukan pertolongan pertama

* Hindari bangunan yang berpotensi roboh

Berdasarkan survei awal diperoleh bahwa Sebagian besar siswa sudah pernah mengalami bencana banjir dan merasakan dampak bencana banjir tersebut (Gambar 1). Jumlah siswa yang menyatakan pernah mengalami banjir sebesar $72 \%$, Sedangkan yang terdampak banjir sebanyak $66 \%$. Sebagian besar siswa juga sudah mengetahui SOP mitigasi bencana banjir, walaupun jumlah yang belum mengetahui SOP masih banyak, yaitu $44 \%$. Sekitar $78 \%$ siswa menyatakan tidak ada tempat yang aman dari bencana banjir di lingkungan sekitarnya.

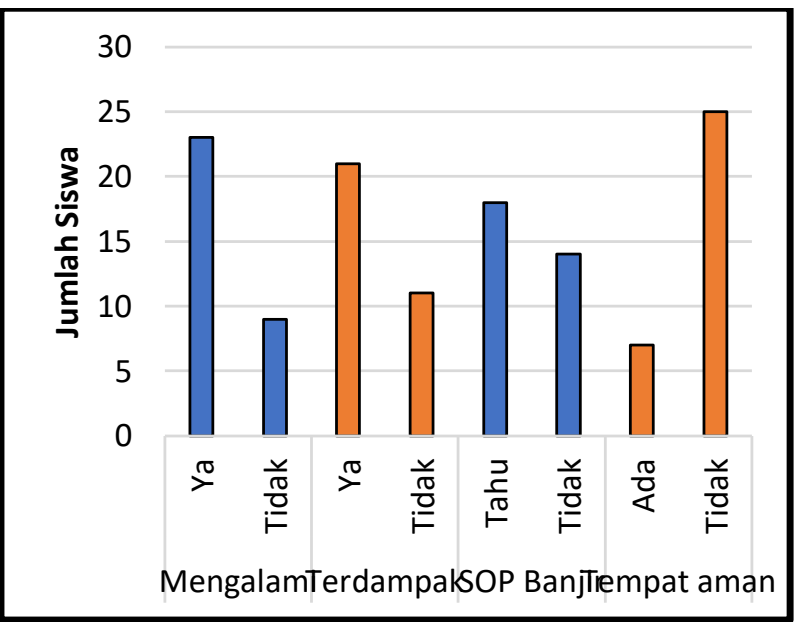

Gambar 1. Pengalaman Siswa dengan Bencana Banjir

Jumlah siswa yang mengalami dan merasakan dampak bencana gempa bumi jauh lebih besar daripada bencana banjir. Sekitar 93\% siswa mengaku mempunyai pengalaman dengan gempa bumi, dan $100 \%$ siswa merasa terdampak oleh bencana gempa bumi tersebut (Gambar 2). Kebanyakan siswa (63\%) yang sudah mengetahui SOP jika terjadi gempa bumi. Di dalam angket tidak ditanyakan dari mana mereka memperoleh informasi tentang SOP bencana gempa bumi.

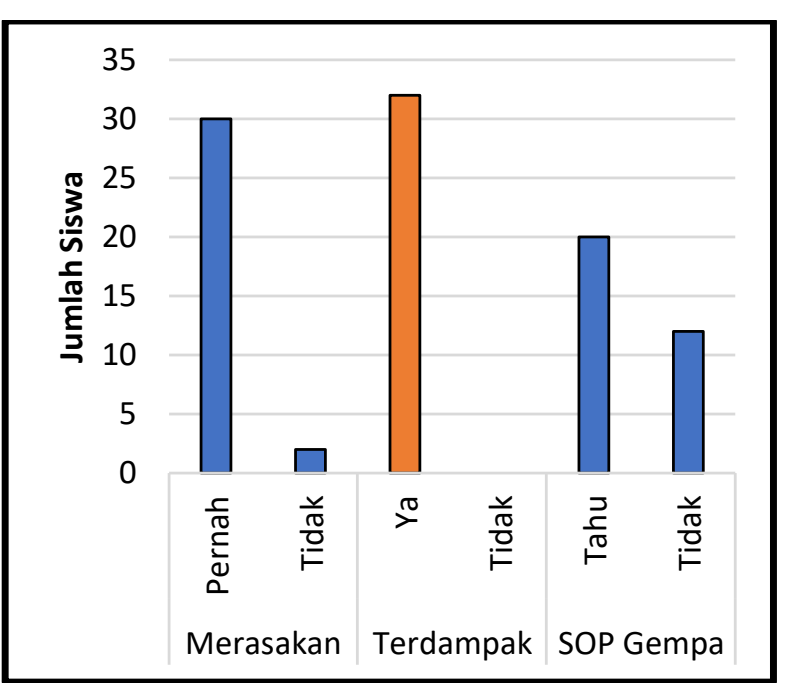

Gambar 2. Pengalaman Siswa dengan Bencana Gempa Bumi

Selama kegiatan sosialisasi berlangsung peserta terlihat antusias mendengarkan sosialisasi yang kami lakukan dengan metode presentasi dan simulasi. Antusiasme ini dapat dilihat dari para peserta yang menyimak penjelasan tentang mitigasi bencana dengan tertib. Setelah pemberian materi kami buka sesi tanya jawab yang diketahui terdapat 2 siswa dan 2 siswi yang mengajukan pertanyaan. Setelah kegiatan sosialisasi berakhir siswa dibagikan link kuesioner terkait sosialisasi yang baru saja diselenggarakan untuk melihat dampak yang dirasakan siswa setelah mengikuti sosialisasi edukasi sadar bencana. Dari 47 peserta yang datang, diperoleh 20 data peserta kuesioner.

Berikut adalah grafik kuesioner sesudah dilakukannya kegiatan sosialisasi SOP mitigasi bencana :

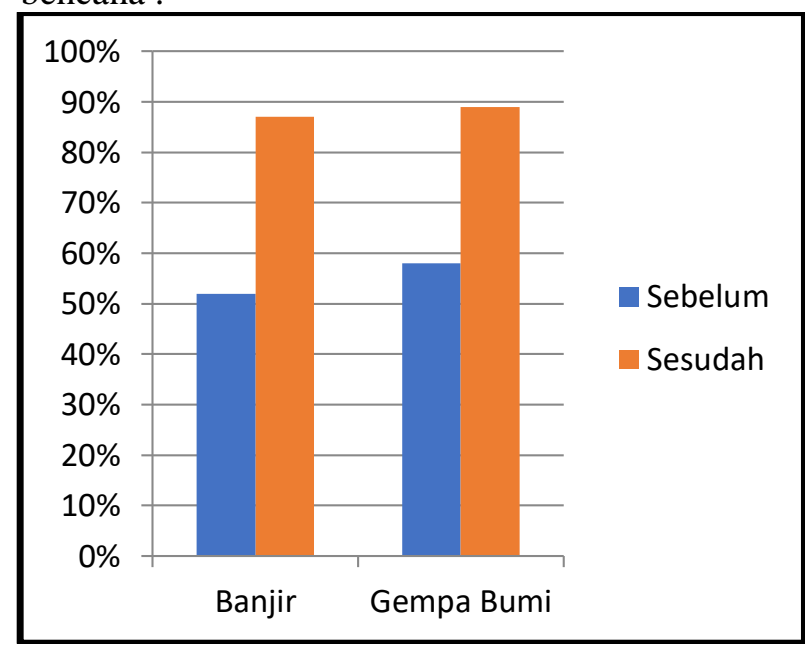

Gambar 3. Peningkatan Pengetahuan Siswa SMKN Sebelum dan Sesudah Sosialisasi SOP Mitigasi Bencana 
Berdasarkan pada grafik menunjukkan bahwa peserta kegiatan sosialisasi ini mengalami peningkatan pengetahuan prosedur SOP mitigasi prabencana, saat bencana dan pascabencana. Pada topik bencana banjir sebelum dilakukan sosialisasi pengetahuan siswa sebesar $52 \%$, dan setelah dilakukan sosialisasi mengalami peningkatan pengetahuan SOP mitigasi bencana banjir sebesar $87 \%$.

Pada topik bencana gempa bumi sebelum dilakukan sosialisasi pengetahuan siswa sebesar $58 \%$, dan setelah dilakukan sosialisasi mengalami peningkatan pengetahuan SOP mitigasi bencana gempa bumi sebesar 89\%. Jumlah siswa yang mengalami peningkatan pengetahuan SOP bencana gempa bumi sebelum dan sesudah dilakukan sosialisasi lebih besar daripada bencana banjir. Maka dari itu, kegiatan sosialisasi SOP mitigasi bencana banjir dan gempa bumi yang telah dilakukan memberikan dampak yang baik dan memuaskan bagi siswa.

Hasil dari kegiatan sosialisasi ini berupa poster SOP bencana banjir dan gempa bumi sebanyak 2 lembar. Poster tersebut diharapkan dapat memberikan informasi dan pengetahuan yang penting terkait SOP yang harus dilakukan ketika bencana melanda.

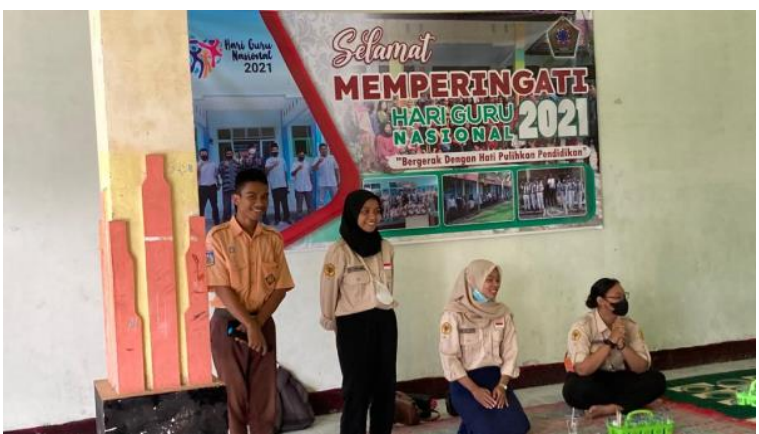

Gambar 4. Kegiatan Sosialisasi SOP Mitigasi Bencana Banjir dan Gempa Bumi

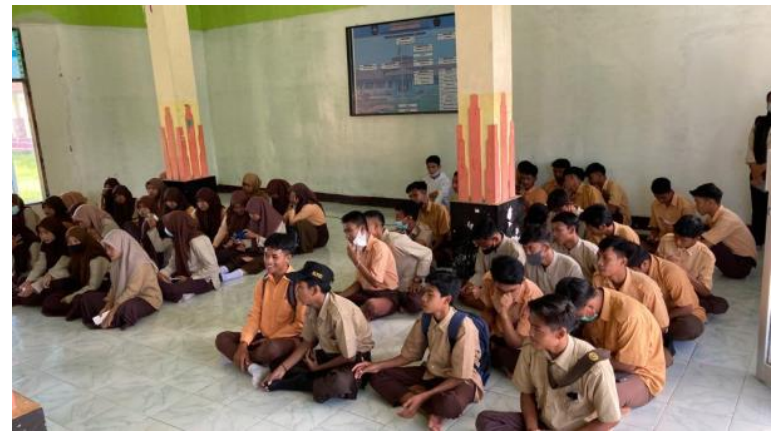

Gambar 5. Siswa-Siswi SMKN 1 Sekotong

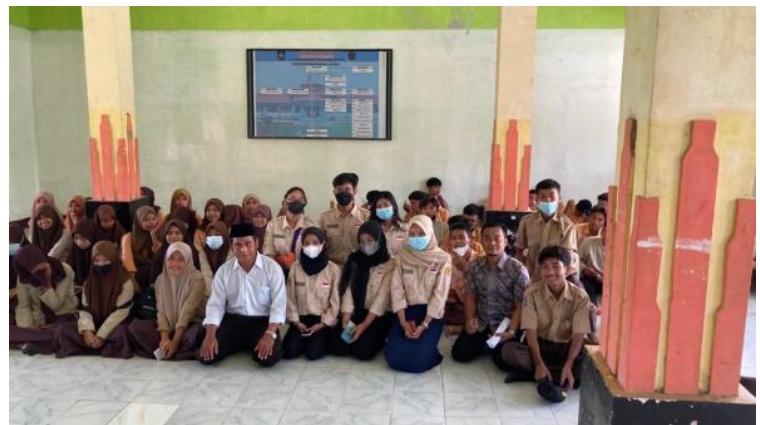

Gambar 6. Tim Mahasiswa KKN bersama Guruuru SMKN 1 Sekotong

\section{Kesimpulan}

Kegiatan sosialisasi SOP mitigasi bencana banjir dan gempa bumi ini memberikan dampak dan pengaruh yang baik dan cukup tinggi. Pengetahuan tentang SOP mitigasi bencana banjir dan gempa bumi sangat diperlukan untuk lebih waspada ketika tanda-tanda bencana datang dan mengetahui langkah-langkah yang harus dilakukan ketika bencana datang. Dengan demikian, dapat dikatakan bahwa pengabdian ini berhasil dilaksanakan dengan baik sehingga peserta SMKN 1 Sekotong sudah memiliki kesiapsiagaan yang baik dalam menghadapi risiko bencana banjir dan gempa bumi.

\section{Ucapan Terima Kasih}

Kegiatan sosialisasi ini merupakan salah satu program kerja utama tim mahasiswa KKN Terpadu Desa Cendi Manik yang bertema Desa Tanggap Bencana (DESTANA). Kami berterima kasih kepada Kepala Sekolah SMKN 1 Sekotong, guru beserta jajarannya karena sudah memberikan waktu dan kesempatan kepada kami. Kegiatan lapangan dibantu oleh guru SMKN 1 Sekotong dan tim mahasiswa KKN PLP Terpadu 2021.

\section{Daftar Pustaka}

Buku Saku Tanggap Tangkas Tangguh Menghadapi Bencana, Edisi 2017: BNPB

Haryanto, Heru, 2001, Manajemen Penanggulangan Bencana, Profil Manggala Agni, Jakarta.

Maryono, Agus, 2005, Menangani Banjir, Kekeringan dan Lingkungan, Gadjah Mada University Pers, Yogyakarta

Pinuji, Sridewanto, 2019, Belajar Mitigasi Bencana dari

Jepang,

https://www.kompasiana.com/dewantoedi/5 $\underline{\text { d667fb30d82306f300cd742/belajar- }}$ 
mitigasi-bencana-dari-jepang, di akses tanggal 04 Januari 2022.

Purnama, Sang Gede, 2017, Modul Manajemen Bencana, Universitas Udayana, Denpasar.

UU No. 24 Tahun 2007 Tentang Penanggulangan Bencana Jakarta: Kementerian Hukum dan Hak Asasi Manusia 